\title{
38. Water services and cooperation
}

\author{
Tapio S. Katko \\ UNESCO Chair in Sustainable Water Services, Tampere \\ University of Technology (TUT), Finland \\ Jarmo J. Hukka \\ Tampere University of Technology (TUT), Finland \\ D.A. Mashauri \\ Polytechnic of Namibia (PoN), Namibia \\ E.N. Nyangeri \\ University of Nairobi (UoN), Kenya
}

\section{Background and objectives of the UNESCO Chair in Sustainable Water Services}

The biggest global challenges of mankind are all, in one way or another, related to water - its availability, occurrence and quality. In terms of water uses, community water supply is generally set as the highest priority for policymakers (Katko and Rajala 2005), yet water quality, water pollution control and wateruse conflicts are also a huge concern in many areas.

Currently some 0.8 billion people lack access to improved sources of drinking water, and as many as 2.5 billion cannot access basic sanitation (United Nations Children's Fund (UNICEF)/World Health Organization (WHO)2012). Looking beyond the Millennium Development Goals, water was identified as one of the seven Critical Issues at the UN Conference on Sustainable Development (Rio+20 Summit) in 2012. At Rio+20, UN-Water emphasised that the success of the broader green economy depends on sustainable, integrated and resourceefficient management of water resources, and on safe and sustainable provision of water supply and adequate sanitation services (UN-Water 2012). 
The UNESCO Water Chair No. 27 in Sustainable Water Services (UNECWAS) was established at Tampere University of Technology (TUT), Finland, in 2012, and is linked to the Capacity Development in Water and Environmental Services (CADWES) research team based at TUT. The foci of the Chair are management, development, governance, policy and institutional issues associated with water services, particularly urban and rural water supply and wastewater services.

The overall development objective of the Chair is to promote education and research on sustainable water governance, especially services, based on co-creation principles (see Frontier Strategy 2009) and the needs of local communities. A major objective is also to strengthen knowledge creation and sharing and enhance the capacity of partners through North-South-South collaboration between six universities in the South, two UNESCO centres in the North, and three other European partners.

\section{Research agenda}

\section{Reform processes}

The two biggest challenges confronting the water supply and sanitation sector in both industrialised and developing countries are increasing coverage and infrastructure maintenance (Prasad 2007). Many developing countries are presently undergoing or planning substantial policy and institutional reforms of their water sector to overcome these challenges. Typically, these processes entail reform of both policy and the legal and administrative water rights framework (Aagaard and Ravnborg 2006). These reform processes are often driven by foreign experts and donors. International water policies and strategies have in the past, however, concentrated on a few fashionable and, based on research, questionable aspects - like privatisation of urban water delivery - instead of being holistic and comprehensive (Seppälä 2004). Although the reforms have been on the agenda for several years in the south, little research has been carried out on how reforms are implemented and the process occurs.

\section{Water access as an economic good or a human right?}

In 1992 a high-level meeting of water experts released the Dublin Statement on Water and Sustainable Development (ICWE 1992), also known as the Dublin Principles, that would provide the foundation for Integrated Water Management and subsequent thinking on water. Dublin principle no. 4 recognised that water has an economic value in all its competing uses and it should be treated as an economic good: 'managing water as an economic 
good is an important way of achieving efficient and equitable use, and of encouraging conservation and protection of water resources' (Global Water Partnership (GWP) no date). The same principle also pointed out, however, the vital importance of recognising the fundamental right of all human beings to have access to clean water and sanitation at an affordable price.

Shortly after the Dublin Principles were developed - with the economic good aspect being the main emphasis of subsequent interpretations - privatisation of water supply in developing countries emerged, largely at the prompting of international financial bodies. As Franceys (2008) mentions, this 'privatisation decade' lasted roughly from 1995-2003. The belief behind it was that private investments could be attracted through the involvement of multinational companies. For many reasons this has not been the case, and it seems that multinational companies are, rather, withdrawing from water services operations in developing economies (Annez 2006; Hukka and Katko 2003; Bakker 2010; Castro 2008). One of the main pitfalls was the question of regulation and the fact that private operations require a strong public sector and regulation capacity. In several cases, in Latin America and even in Paris and Berlin, municipalities have assumed responsibility after the concession or operational contract expired. Consequently, some 90 per cent of the world's water utilities are currently publicly owned and managed; in sewage the share is about 95 per cent (Hall et al. 2011).

After gaining independence in the 1960s and 1970s, many Sub-Saharan countries introduced a free water policy. It was considered justified in the prevailing political climate, but soon proved unrealistic (Mashauri and Katko 1993). The mainland of Tanzania, for example, abandoned its free water policy at the national level in the 1990s, while Zanzibar, the other part of the United Republic, held out until 2006. Yet, water as a basic human right was promoted by the United Nations Committee on Economic, Social and Cultural Rights, November 2002, which reminded that access to water as a human right - a social and cultural good, not merely an economic commodity - defines the public nature of water as 'a limited natural resource and a public commodity fundamental to life and health'. This process continued and culminated in the historic United Nations (2010) resolution 'Right to water and sanitation' in July 2010.

\section{Governance and stakeholders}

It is clear from the above discussion that water services governance has multiple objectives and criteria to incorporate. Beyond the economic good/human right distinction, these also include: balancing the water requirements of households, food production, energy production and the environment. Besides, water also has various dimensions as a cultural good, common pool resource, natural resource, public good and social good. 
The numerous examples of different water requirements and dimensions stated above show how strong external pressures can be applied to water services. Indeed, the operational environment of water services is complex with a number of stakeholders whose preferences and priorities can create conflicts (see Figure 1). Whatever the priorities, it is obvious that mechanisms are required to co-ordinate and balance various interests and, particularly, to keep in mind the fundamental purpose of water services: to serve citizens and the society at large.

As pointed out by United Nations Economic and Social Commission for Asia and the Pacific (UNESCAP) (2003), addressing inefficiencies and shortcomings of water and sanitation service production are essentially a governance problem in many countries. Failure to observe good governance principles is considered to be one of the root causes of all major problems associated with public and private sector administration. In the case of water, for example, the 2nd World Water Development Report (WWDR2) (UN-Water 2006) noted the linkages between 'water and poverty', water and governance' and 'water and environment', and emphasised that 'the water crisis is essentially a crisis of governance'.

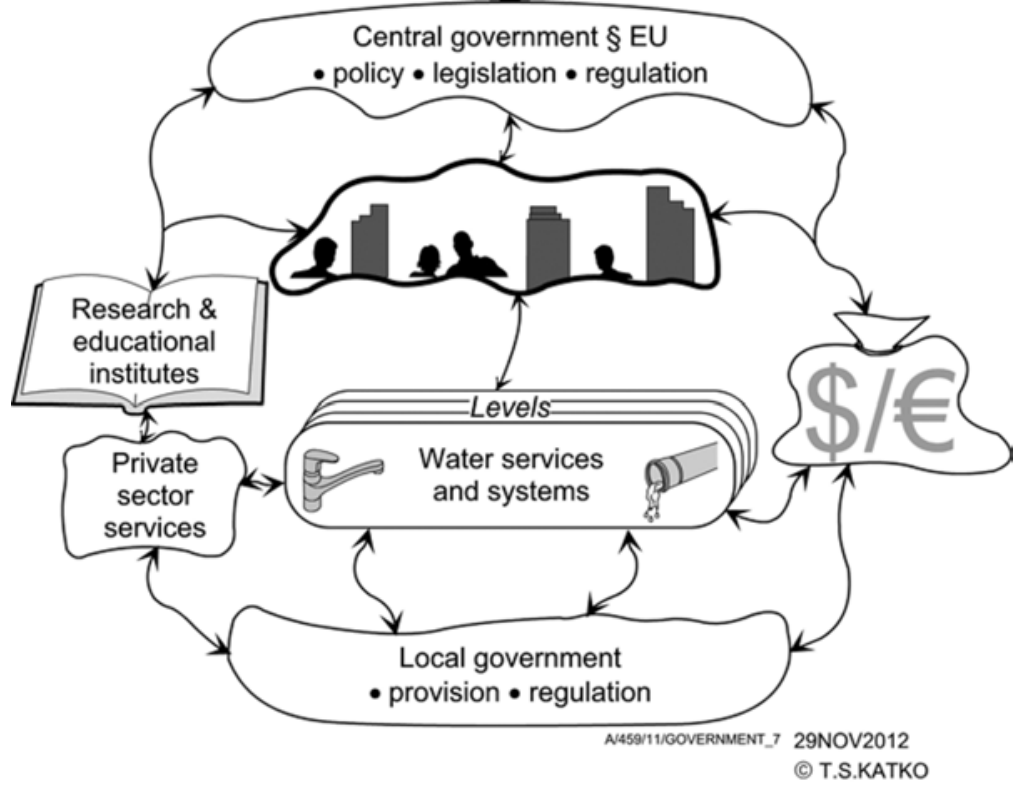

Figure 1: Internal domain framework: major stakeholders of water services

Source: Authors' research.

Good governance is participatory, consensus-oriented, accountable, transparent, responsive, effective and efficient, equitable and inclusive and follows the rule of law (UNESCAP no date). It also ensures that corruption is minimised, the views of minorities are taken into account, and that the most vulnerable members of society are considered in decision-making. It is also responsive to 
the future needs of society. One positive example of movement towards these standards in recent times are the national transparency activities now common in developing nations, such as Kenya (Transparency International Kenya (TIK) 2014) and Uganda (Transparency International Uganda (TIU) 2014). It should be noted, however, that whatever the water governance systems and frameworks present in any country, the likelihood of achieving better and more sustainable development is low without educated experts.

\section{The importance of history}

The current challenges of water-sector reform show how history and past policies and decisions impact our futures. The concept of path-dependence, which originated in economics, has recently been applied to the history of technology (Melosi 2000). The premise is that major decisions may have postponed the introduction of certain systems, decisions may have been made that limit options, or decisions may have been made that severely restrict available options (Figure 2). The importance of these factors are evidenced in historical research of water-sector reforms in Kenya (Nyangeri 2011).

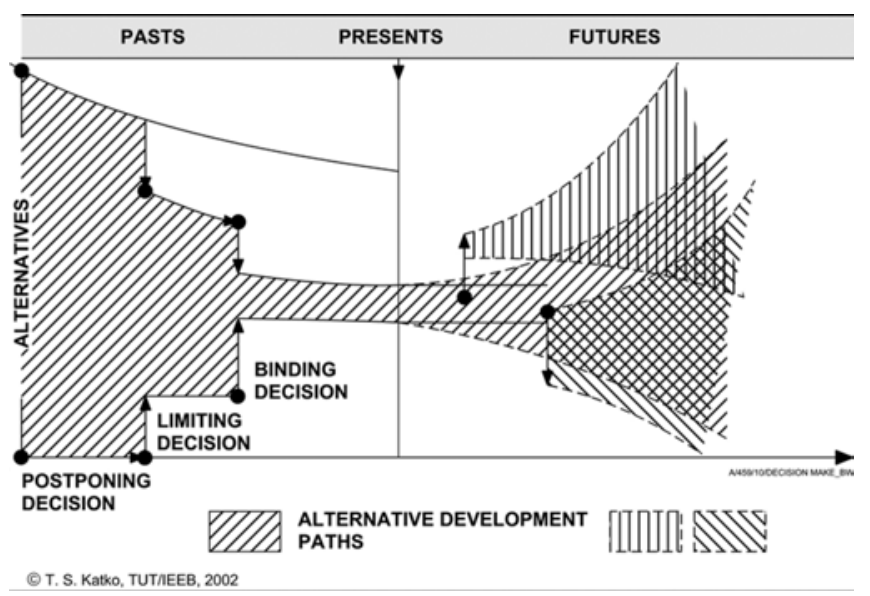

Figure 2: Path dependence: postponing, limiting and binding decisions and their impacts on future options

Source: Kaivo-oja et al. 2004.

Presents (or potential present states) are bound by laws and regulations, compliance with them and their enforcement, and political objectives and decisions that are inevitably related to alternative futures. Futures (or potential future states) can be classified as possible, credible and preferable. Analogies and path dependencies link pasts (or alternative past states), presents and futures to each other (Juuti and Katko 2005). The plural form is used deliberately to point out that several interpretations of each time dimension exist. Note that 
an understanding of water-sector reforms requires a lengthy period to analyse the driving forces across time, and the implications of changes and strategic decisions need to be considered for each period.

Futures researchers emphasise the evolutionary nature of development. Accordingly, development and technology are not deterministic and bifurcations (or turning points) are bound to occur, as shown in Figure 3. Sometimes revolving paths are encounterd, such as in the selection of urban raw-water sources in Finland. In the late 1800s groundwater was favoured by cities, this declined in the 1920s, began again in the 1960s, and has now been contested in the early twenty-first century (Katko et al. 2006).

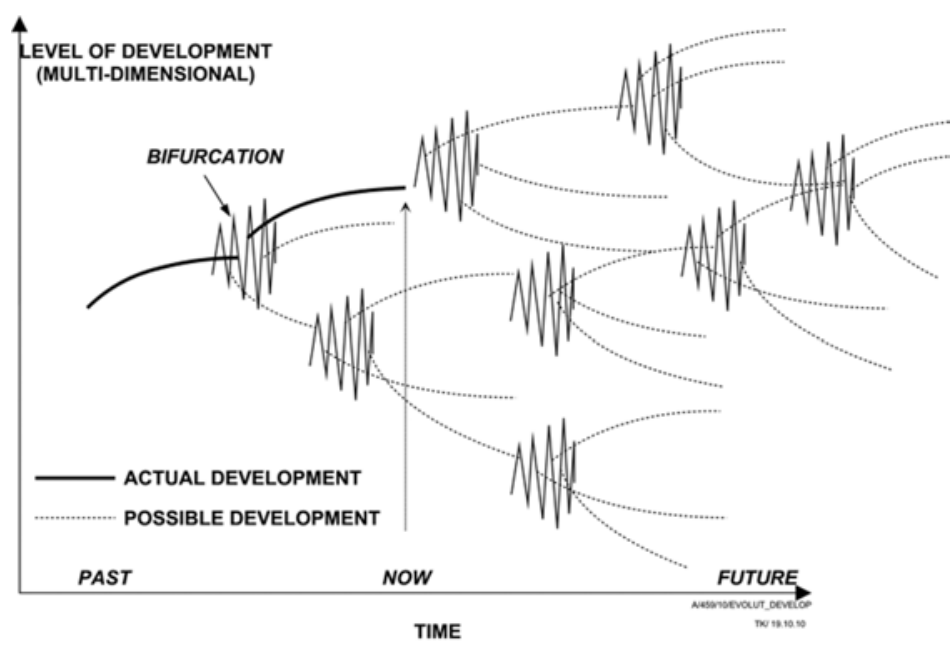

Figure 3: Bifurcate nature of technological development

Source: Adapted from Mannermaa 1991.

\section{Common research agendas in both North and South}

The current research themes of the partners of the UNESCO Chair show that social needs in the water services sectors of the South and the North are remarkably similar: regionalisation, operational improvements, pricing, asset management, rehabilitation, ageing infrastructure, ageing workforce and tacit knowledge management, small systems management, public-private collaboration, leadership and stewardship, more transparent decision-making, and significance of water.

An example of common research agendas is the broad issue of ageing water infrastructure, though the physical manifestation of the issues may vary greatly by location. A recent study in Finland (Heino et al. 2011) based on the views of 48 sector experts showed this to be the most severe challenge to water services. Similar findings have been made in other industrialised countries, such as 
Sweden, Norway and the United States. Moreover, ageing infrastructure is also one of the biggest challenges in the Sub-Saharan region, in addition to related specific issues such as delivery challenges in peri-urban and unplanned areas.

Tapio S. Katko is Adjunct Professor in Water Services Development and the UNESCO Chairholder in Sustainable Water Services.

Jarmo J. Hukka is Adjunct Professor in Futures Research in the Water Sector, both at TUT.

D.A. Mashauri is ADC-WATERNET Professorial Chair of IWRM at PoN and Associate Dean, School of Engineering.

E.N. Nyangeri is Associate Professor at University of Nairobi.

\section{References}

Aagaard, C. and Ravnborg, H.M., 2006. 'Water reform-implications for rural poor people's access to water', Danish Institute for International Studies Brief.

Annez, P.C., 2006. 'Urban infrastructure finance from private operators: what have we learnt from recent experience?', World Bank Policy Research Working Paper 4045.

Bakker, K., 2010. Privatizing water: Governance failure and the world's water crisis, Cornell University Press.

Castro, J.E. 2008. 'Neoliberal water and sanitation policies as a failed development strategy: lessons from developing countries' in E. Brown (ed.) Progress in Development Studies Special Issue on 'GATS and development: the case of the water sector', 8(1):63-83.

Franceys, R. 2008. 'GATS, "Privatization" and institutional development for urban water provision: future postponed?', Progress in Development Studies $8(1): 45-58$.

Frontier Strategy, 2009. 'CO-CREATION'S 5 GUIDING PRINCIPLES or ... what is successful co-creation made of?'. Available at: http://fronteerstrategy. blogspot.it/2009/04/co-creations-5-guiding-principles-or.html.

Global Water Partnership (GWP), no date. 'IWRM principles'. Available at: http://www.gwp.org/en/The-Challenge/What-is-IWRM/IWRM-Principles/.

Hall, D., Lobina, E. and Corral, V., 2011. 'Trends in water privatisation'. PSIRU. Available at: http://www.psiru.org/reports/trends-water-privatisation. 
Heino, O.A., Takala, A.J. and Katko, T.S., 2011. 'Challenges to Finnish water and wastewater services in the next 20-30 years', E-Water.

Hukka, J. and Katko, T., 2003. 'Water privatisation revisited - panacea or pancake?', IRC Occasional Paper Series No. 33. Delft, the Netherlands. Available at: http://www.irc.nl/page/6003.

International Conference on Water and the Environment (ICWE), 1992. 'The Dublin Statement on Water and Sustainable Development'. Available at: http://www. un-documents.net/h2o-dub.htm.

Juuti, P. and Katko, T. (eds), 2005. Water, Time and European Cities. History matters for the futures. Available at: htpp://www. WaterTime.net.

Kaivo-oja, J.Y., Katko, T.S. and Seppälä, O.T., 2004. 'Seeking for convergence between history and futures research', Futures 36:527-47.

Katko, T.S. and Rajala, R.P., 2005. 'Priorities for fresh water use purposes in selected countries with policy implications', International Journal of Water Resources Development 21(2):311-23.

— L Lipponen, A.M. and Rönkä, E.K.T., 2006. 'Ground water use and policy in community water supply in Finland', Hydrogeology Journal 14(1-2):69-78.

Prasad, N., 2007. 'Social policies and water sector reform', Markets, Business and Regulation Programme Paper Number 3 September 2007. UNRISD.

Mannermaa, M., 1991. 'Evolutionary futures research', Acta Futura Fennica no. 2.

Mashauri, D.A. and Katko, T., 1993. 'Water supply development and tariffs in Tanzania: from free water policy towards cost recovery', Environmental Management 17(1):31-9.

Melosi, M.V., 2000. Sanitary City, Johns Hopkins University Press.

Nyangeri, E.N., 2011. 'Importance of water in Kenya, challenges and reforms'. Tampere University of Technology. Presentation on 19 August 2011.

Seppälä, O.T., 2004. 'Visionary management in water services: Reform and development of institutional frameworks'. TUT Doctoral dissertation no. 457.

Transparency International Kenya, no date. Available at: http://www. tikenya.org/.

Transparency International Uganda, no date. Available at: http://www. tiuganda.org/. 
United Nations Economic and Social Commission for Asia and the Pacific (UNESCAP), 2003. 'What is good governance?', United Nations Economic and Social Commission for Asia and the Pacific. Available at: http://www. unescap.org/huset/gg/governance.htm.

—, no date. 'What is good governance?'. Available at: http://www.unescap. org/pdd/prs/ProjectActivities/Ongoing/gg/governance.asp.

United Nations Children's Fund (UNICEF)/World Health Organization (WHO), 2012. 'Joint Monitoring Programme for Water Supply and Sanitation, progress on drinking water and sanitation: 2012 update'. Available at: http:// www.unicef.org/media/files/JMPreport2012.pdf.

United Nations (UN), 2010. Resolution adopted by the General Assembly 64/292. The human right to water and sanitation. Available at: http://www.un.org/ga/ search/view_doc.asp?symbol=A/RES/64/292.

UN-Water, 2006. The 2nd United Nations World Water Development Report: Water, a shared responsibility. Available at: http://www.unesco.org/new/en/ natural-sciences/environment/water/wwap/wwdr/.

, 2012. 'Water in a green economy'. A Statement by UN-Water for the UN Conference on Sustainable Development 2012 (Rio+20 Summit). Available at: http://www.unwater.org/downloads/UNW_RIOSTATEMENT.pdf. 
This text taken from Global Water: Issues and Insights by R. Quentin Grafton, Paul Wyrwoll, Chris White and David Allendes, published May 2014 by ANU Press, The Australian National University, Canberra, Australia. 